\title{
Foreword: special issue on more than more microsystems
}

\author{
Bharat Bhushan ${ }^{1}$
}

Published online: 15 October 2021

(C) The Author(s), under exclusive licence to Springer-Verlag GmbH Germany, part of Springer Nature 2021

This special issue on "More than Moore Microsystems" consists of selected best papers presented "2018 IEEE Electron Device Kolkata Conference (2018 IEEE EDKCON)" held in the Kolkata, India during November 24-25, 2018.

The conference covered broad topics on current developments and future trends in device technology and materials science for application in circuits and microsystems. Authors of selected papers from the conference were invited to submit full length papers for possible inclusion in this special issue of Microsystem Technologies (MST). All papers were refereed according to the rigorous journal standards. The review process was coordinated by guest editors: Profs. Jyotsna Kumar Mandal and Angsuman Sarkar. Eighteen papers were accepted for publication in this issue.

We hope that readers find the papers in the issue to be informative.

Prof. Bharat Bhushan

Co-Editor in Chief, MST

October 2021

Publisher's Note Springer Nature remains neutral with regard to jurisdictional claims in published maps and institutional affiliations.

Bharat Bhushan

bhushan.2@osu.edu

1 Ohio State University, San Jose, USA 